\title{
SHANK2 Gene
}

National Cancer Institute

\section{Source}

National Cancer Institute. SHANK2 Gene. NCI Thesaurus. Code C147939.

This gene is involved in linking the postsynaptic membrane to glutamate receptors. 